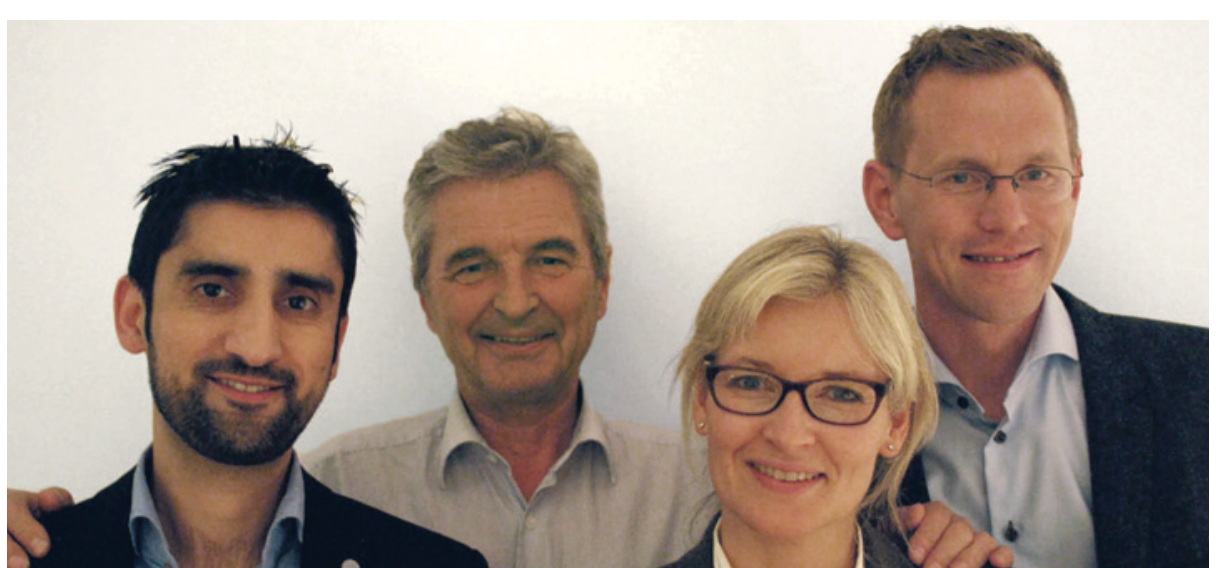

Fra venstre til høyre: Biveileder Sheraz Yaqub, hovedveileder Tom Øresland, forskningskoordinator Merete Helgeland og stipendiat Johannes Kurt Schultz. Foto: Michela Monteleone

\title{
Kirurgi ved perforert divertikulitt
}

Laparoskopisk skylling var ikke bedre enn colonreseksjon ved perforert divertikulitt, viste en ny norsk-svensk studie.

Akutt colonreseksjon, som er den hittil vanligste behandlingen ved perforert divertikulitt, er assosiert med høy mortalitet og morbiditet. Laparoskopisk skylling ble introdusert som et mindre invasivt alternativ for pasienter med perforert divertikulitt og purulent peritonitt, og i enkelte kohortstudier har man antydet at metoden kan redusere både mortalitet og morbiditet.

I en norsk-svensk studie som nylig ble publisert i tidsskriftet JAMA, og med deltagelse fra 21 sykehus, ble laparoskopisk skylling og primær reseksjon hos pasienter med perforert divertikulitt sammenlignet (1). 199 pasienter med CT-verifisert perforert divertikulitt og operasjonsindikasjon ble i perioden 2010-14 randomisert til enten laparaskopisk skylling eller primær colonreseksjon. Primære endepunkter var alvorlige postoperative komplikasjoner innen 90 dager, dvs. komplikasjoner som krever intervensjon i narkose eller livstruende komplikasjoner med organsvikt eller død. Det ble dessuten redegjort for hvorfor enkelte pasienter ikke ble tatt med i studien.

Det var ingen statistisk signifikante forskjeller i alvorlige komplikasjoner mellom de to gruppene, men signifikant flere reoperasjoner innen tre måneder blant dem som ble behandlet med laparoskopisk skylling: 20,3\% mot 5,7\% (ARR 14,6\% - 95\% KI 3,5\%$25,6 \%, p=0,013)$. I observasjonstiden ble det også avdekket fire tilfeller av tykktarmskreft som ikke ble oppdaget ved skylling.

- Studien som ble initiert og ledet av gastrokirurger ved Akershus universitetssykehus, er den største randomiserte studien gjennomført på en slik pasientpopulasjon, forteller stipendiat Johannes Schultz, som er førsteforfatter av artikkelen.

- Det er mange utfordringer knyttet til det å inkludere pasienter med en alvorlig, akutt lidelse i en slik studie, sier han. - Det lyktes oss å inkludere halvparten av alle inkluderbare pasienter. Studien styrkes også av konsekvent monitorering, bortfallsanalyse og en pragmatisk studiedesign, der pasientene ble inkludert i en hverdagssituasjon på store og små akuttkirurgiske sykehus, og der vakthavende kirurg gjennomførte operasjonene, sier han.

- Studien viser at laparoskopisk skylling ved perforert divertikulitt med purulent peritonitt ikke reduserer morbiditet sammenlignet med primær reseksjon. Derimot medfører denne metoden flere akutte reoperasjoner og risiko for å overse tykktarmskreft som årsak til perforasjon, sier Schultz.

\section{Forskergruppen}

Gastrokirurgisk avdeling ved Akershus universitetssykehus har et aktivt forskningsmiljø innen kolorektalkirurgi, særlig ved divertikkelsykdom, kolorektalkreft og inflammatorisk tarmsykdom. SCANDIVgruppen ble opprettet på initiativ av professor Tom Øresland, som er sisteforfatter på denne artikkelen. Studien var mulig takket være stor entusiasme blant kirurgene ved sykehusene. Den inngår som en del av doktorgradsarbeidet til Johannes Schultz. Gruppen jobber nå med langtidsresultater, og det vil bli veldig spennende å se hvilken behandling pasientene har best nytte av på lang sikt.

\section{Kaveh Halland Rashidi}

Tidsskriftet

\section{Litteratur}

1. Schultz JK, Yaqub S, Wallon C et al. Laparoscopic lavage vs primary resection for acute perforated diverticulitis: The SCANDIV Randomized Clinical Trial. JAMA 2015; 314: 1364-75.
Ordforklaringer

Perforert divertikulitt: Inflammasjon i utposning på tykktarm med perforasjon til bukhulen som i de fleste tilfeller fører til purulent peritonitt og sjeldnere til fekal forurensning av bukhulen.

Purulent peritonitt: Bukhinnebetennelse med puss i bukhulen.

Primær colonreseksjon: Fjerning av den syke tarmdelen, vanligvis colon sigmoideum, som regel med utlegging av endestomi og unntaksvis med primær anastomosering.

Laparoskopisk skylling: Laparoskopisk skylling (lavage) av bukhulen med temperert saltvann til klar skyllevæske og påfølgende drenasje av bukhulen.

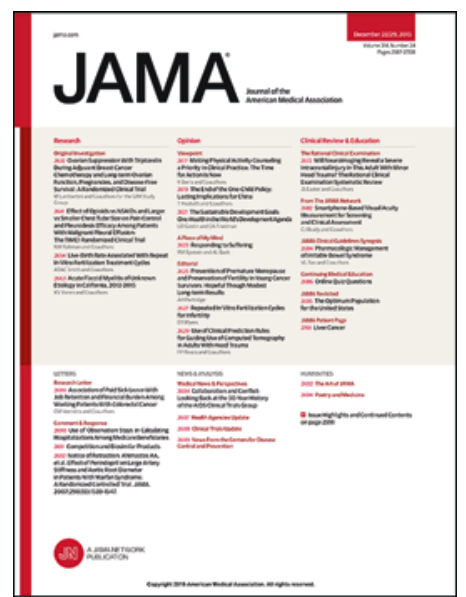

Artikkelen ble publisert i det anerkjente tidsskriftet JAMA 6.10. 2015 